Article

\title{
Citizen Science Confirms the Rarity of Fruit Bat Pollination of Baobab (Adansonia digitata) Flowers in Southern Africa
}

\author{
Peter J. Taylor ${ }^{1, *} *$, Catherine Vise ${ }^{1,2}$, Macy A. Krishnamoorthy ${ }^{3}$, Tigga Kingston ${ }^{3}$ and \\ Sarah Venter ${ }^{4}$ \\ 1 School of Mathematical and Natural Sciences, University of Venda, Private Bag X5050, \\ Thohoyandou 0950, South Africa; catherinev@ewt.org.za \\ 2 Wallace Dale Farm 727MS, PO Box 52, Louis Trichardt, Limpopo 0920, South Africa \\ 3 Department of Biological Sciences, Texas Tech University, Lubbock, TX 79409, USA; \\ macy.krishnamoorthy@ttu.edu (M.A.K.); tigga.kingston@ttu.edu (T.K.) \\ 4 School of Animal, Plant and Environmental Sciences, University of the Witwatersrand, \\ Private Bag 3, WITS 2050, Johannesburg, South Africa; windwaai@mweb.co.za \\ * Correspondence: peter.taylor@univen.ac.za; Tel.: +27-15-962-9326
}

Received: 8 February 2020; Accepted: 12 March 2020; Published: 19 March 2020

\begin{abstract}
The iconic African baobab tree (Adansonia digitata) has "chiropterophilous" flowers that are adapted for pollination by fruit bats. Although bat pollination of baobabs has been documented in east and west Africa, it has not been confirmed in southern Africa where it has been suggested that hawk moths (Nephele comma) may also be involved in baobab pollination. We used a citizen science approach to monitor baobab tree and flower visitors from dusk till midnight at 23 individual baobab trees over 27 nights during the flowering seasons (November-December) of 2016 and 2017 in northern South Africa and southern Zimbabwe (about 1650 visitors). Insect visitors frequently visited baobab flowers, including hawk moths, but, with one exception in southeastern Zimbabwe, no fruit bats visited flowers. Citizen science enabled us to substantiate preliminary conclusions about the relative importance of moth versus bat pollination of baobabs in southern Africa, with important implications for resource management.
\end{abstract}

Keywords: bats; baobab trees; citizen science; pollination

\section{Introduction}

Old World fruit bats (Family Pteropodidae) are important pollinators of plant species throughout the Palaeotropics [1-8]. They are effective pollinators because they transfer large amounts of pollen of varied genotypes among plants and travel relatively long distances [9]. The benefits of bat pollination are such that most bat-dependent plants invest in a chiropterophilous syndrome of floral characteristics to attract bat pollinators. Old World chiropterophilous flowers are typically large and often bell-shaped and prominent, white or pale in color, have a strong musky odor, are cauliflorous or presented on sturdy stems that can support the weight of bats. They typically produce large quantities of pollen and nectar and open at dusk and senesce by morning [10-12]. Although nocturnal insects may also visit bat flowers, bat pollination is commonly needed for effective fruit set [7,13-15].

The African baobab, Adansonia digitata, is widespread on mainland Africa, occurring throughout most of west, east and southern Africa in a variety of habitats from deserts to subtropical forests and in diverse landscapes including rocky ridges, plains, river valleys, and human-modified landscapes such as fields and villages [16-18]. Phylogenetic analysis of baobab populations has found the center of origin to be west Africa, and it is thought that baobabs have been distributed across Africa 
by natural and human-mediated dispersion events [19]. African baobab flowers fit the classic bat pollination syndrome [20], and several species of fruit bats (including Rousettus aegyptiacus, Epomophorus gambianus and Eidolon helvum) have been observed visiting baobabs in large numbers in east and west Africa $[1,2,21]$. Exclusion experiments, in which baobab flowers pollinated by bats were compared to those pollinated by insects, confirm the primary role of bats as baobab pollinators in west Africa [5].

Bat pollination is hypothesized to be important for African baobabs because trees are self-incompatible [20,22] and occur at densities averaging 2 trees/ha [18]. As long-distance fliers capable of carrying large pollen loads, bats should be effective pollinators and central to reproductive success in many populations. However, in contrast to east and west Africa, no evidence is yet available for the pollination of baobabs by fruit bats in southern Africa, and $98 \mathrm{~h}$ of flower visitor observation conducted by S.V. and students yielded not one single fruit bat visitor to a baobab flower in South Africa (Nisa Karimi and Ana Chetty, unpublished data). There are only 6 species of fruit bats in southern Africa (south of the Zambezi River), considerably fewer than the 11 species in East Africa or 22 species in West Africa [23]. Three genera of fruit-eating bats (Rousettus, Eidolon, and Epomophorus) occur in the region coinciding with the distribution of A. digitata in South Africa and Zimbabwe [24]. Although bats have yet to be observed at African baobab trees in southern Africa, hawkmoths (e.g., Nephele comma and Sphingomorpha chlorea) visit baobabs throughout the continent and are the primary pollinator of several species of baobabs endemic to Madagascar [4]. Indeed, Baum [20] suggests that hawkmoths are the ancestral pollinator of Adansonia with specialization to mammalian pollination occurring more recently. This raises the possibility that, in the absence of bat pollinators, African baobabs from southern Africa have come to rely on an ancestral pollinator, albeit with reduced reproductive success.

The possible absence of an important pollinator raises concerns about the vulnerability of the baobab population in southern Africa and the impact this could have on people who rely on baobabs for their livelihoods. Baobabs provide an important source of food, fiber and medicine, and in recent years, the increase in global demand for the fruit powder and seed oil has allowed thousands of African people to earn an income from harvesting the fruit. The sustainable management and use of baobab fruit are the responsibility of harvesters and commercial traders who work closely with the resource and at a regional level, resource managers and policy makers [25]. Thus, it is imperative that the pollinators of this population are established to support persistence and conservation of baobabs in this region.

Citizen science projects have been widely used and acclaimed as a means to promote public awareness about science and conservation while obtaining often large amounts of important scientific data [26]. Citizen science projects can typically achieve far more than would be possible by just a few scientists. In order to obtain quantitative observations about nocturnal baobab flower visitors in southern Africa, and specifically to try to answer the question "Do fruit bats pollinate baobabs in southern Africa?", we recruited citizen scientists (including researchers, students and the wider public) through a public project termed the "Baobab Blitz" to coincide with the flowering seasons (November-December) in 2016 and 2017.

\section{Methods}

The focus of our study comprised the semi-arid "lowveld" of the northern Limpopo Province in South Africa where most of the baobab sites were located (Figure 1). Baobabs in Limpopo are largely associated with the Musina Mopane Bushveld vegetation type [27]. The province experiences long sunny days and dry weather conditions on most days. Mean monthly temperatures are high in summer (October to March), rising to $27^{\circ} \mathrm{C}$ in summer and $20^{\circ} \mathrm{C}$ in winter, with maximum monthly temperatures reaching to over $45^{\circ} \mathrm{C}$. Most precipitation falls in summer, and annual rainfall totals range from about $400-600 \mathrm{~mm}$ but can be as low as $350 \mathrm{~mm}$ in the drier parts [28]. The region is very prone to climate change. At Musina in the Limpopo Valley, over 50 years between 1960 and 2009, average minimum and maximum temperatures in the area have increased by around $1.2{ }^{\circ} \mathrm{C}$ and the number of extremely hot days $\left(>35^{\circ} \mathrm{C}\right)$ per summer has increased by 22 days $[29,30]$. 


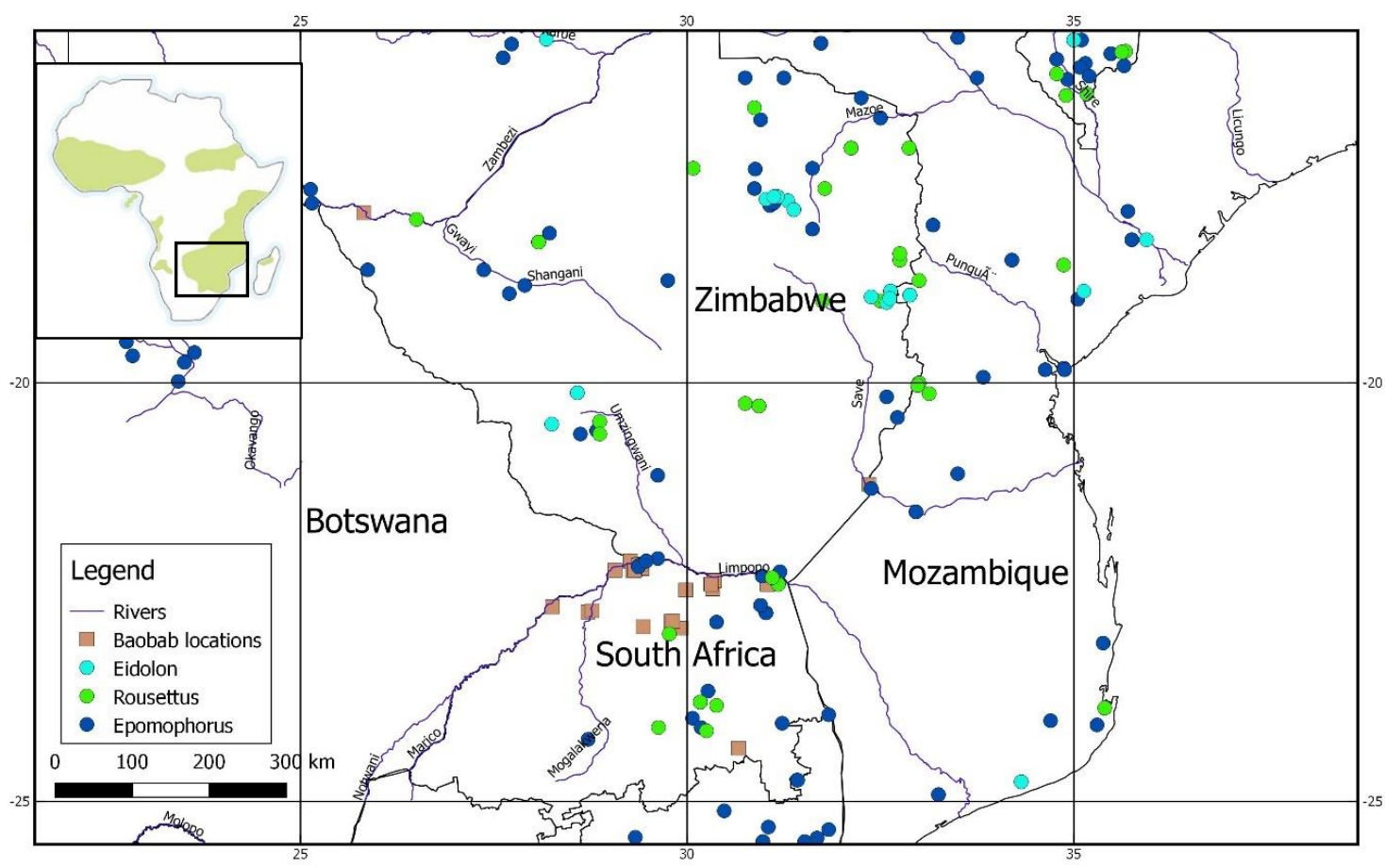

Figure 1. Map of southern African show locations of baobab trees (Adonsonia digitata) surveyed during the "Baobab Blitz" citizen science campaigns in 2016 and 2017 in relation to known occurrence records of fruit bats of the genera Epomophorus, Rousettus and Eidolon [24]. Inset shows the general distribution of Adansonia in Africa and Madagascar.

Baobabs follow a steady state flowering pattern lasting 1-5 months with peak flowering in November of each year [31]. Thus, it was decided that the most reliable month for the survey would be November-December. This is also the time when baobabs produce the most abundant amounts of flowers, suggesting a good time for pollinators to be in the vicinity.

Citizen scientists were recruited to participate in both the November-December 2016 and November 2017 "Baobab Blitz" exercises after an active campaign using posters (Appendix A) and a series of articles in the local Zoutpansberger newspaper in October 2016 [32]), March 2017 [33] and November 2017 [34].

Social media links were also used effectively, including a Facebook page (https://www.facebook. $\mathrm{com} /$ BaobabBlitz) and links to a joint web page of the Vhembe Biosphere Reserve and the South African Research Chairs Initiative (SARChI) Research Chair on Biodiversity Value and Change at University of Venda (http://vhembebiosphere.org/sarchi/projects/baobab-blitz). The project was actively promoted both by the Vhembe Biosphere and the University of Venda's SARChI Research Chair, and Biosphere members and University students volunteered to take part in the Baobab Blitz exercise.

The data were obtained by guiding participants (usually two or more in a group) to spend at least one night (from 18:00 to midnight) at a flowering baobab tree. Using a standard datasheet and instructions (Appendix B, Appendix C), volunteers conducted visual scans at 15-min intervals of the number of visitors to the flowers or tree. 'Flower visitors' were those animals that visited a specific flower on the tree, making contact with it, while a 'tree visitor' was present within the crown of the tree, but had no contact with a flower. Flower and tree visitors were classified into three groups: moths, bats and others. Bat visitors to the tree and/or flower included both insectivorous and frugivorous bats (but a comment fields was used by respondents to differentiate between them). Visitors in the "other" category were identified in the comments field for that interval. Additional details were recorded about the location of the tree, the number of flowers open (2016), and the weather during the night of observation (Table 1, Appendix B, Appendix C). The datasheets were scanned by each of the participants and emailed to the organizers of the Blitz. 
Table 1. Details of 27 nights recorded at 23 Baobab tree locations during 2016 and 2017, where citizen scientists conducted observations of flower visitors as part of the "Baobab Blitz" project. N refers to number of observers. Where multiple locations were recorded within protected areas, particular locations are noted by abbreviated codes in parentheses.

\begin{tabular}{|c|c|c|c|c|c|c|c|c|c|c|c|c|}
\hline Locality Name & Lat. & Long. & Date & $\mathbf{N}$ & $\begin{array}{c}\text { Age } \\
\text { Range }\end{array}$ & Weather & Wind & $\begin{array}{l}\text { Experience } \\
\text { Level } \\
\text { (Researchers/ } \\
\text { Students } \\
\text { Present or } \\
\text { Absent) }\end{array}$ & $\begin{array}{l}\text { Time } \\
\text { Start }\end{array}$ & $\begin{array}{l}\text { Time } \\
\text { End }\end{array}$ & $\begin{array}{l}\text { No. } \\
\text { Flowers } \\
\text { Open }\end{array}$ & Land Use \\
\hline Hector and Hazel's Farm & -22.87 & 29.79 & 6-Nov-16 & 6 & 24 & clear & slight breeze & Present & $18: 30$ & 23:00 & 27 & cattle and game farm \\
\hline Goro & -22.94 & 29.43 & 19-Nov-16 & 3 & 24 & partly cloudy & slight breeze & Present & $18: 00$ & $21: 45$ & 55 & game farm \\
\hline Mapesu Private Game Reserve & -22.15 & 29.26 & 18-Nov-16 & 4 & $17-38$ & rain & strong wind & Absent & $18: 00$ & $23: 00$ & 39 & game farm \\
\hline The Oaks Village & -24.37 & 30.66 & 18-Nov-16 & 2 & $22-32$ & overcast & slight breeze & Absent & $17: 30$ & $22: 30$ & 8 & cattle farm \\
\hline Skirbeek 73MT & -22.48 & 30.33 & 18-Nov-16 & 1 & 57 & overcast & strong wind & Absent & $18: 00$ & $22: 00$ & 4 & game farm \\
\hline Mogalakwena Game Reserve & -22.76 & 28.72 & 18-Nov-16 & 7 & $20-42$ & overcast & no wind & Present & $18: 00$ & $21: 00$ & - & game farm \\
\hline Mogalakwena Game Reserve & -22.74 & 28.77 & 19-Nov-16 & 6 & $20-48$ & rain & slight breeze & Present & 18:00 & 23:00 & 8 & game farm \\
\hline $\begin{array}{l}\text { Mmabolela Estates, Farm Tuli, } \\
\text { district Maasstroom }\end{array}$ & -22.70 & 28.26 & 18-Nov-16 & 2 & $68-69$ & partly cloudy & strong wind & Present & 19:00 & 22:00 & 21 & game farm \\
\hline Chilo Gorge Lodge, Zimbabwe & -21.23 & 32.35 & 25-Nov-16 & 3 & $45-55$ & overcast & strong wind & Present & $18: 00$ & $23: 00$ & 130 & game farm \\
\hline Elgen (Skelmwater Research Plot) & -22.50 & 29.98 & 19-Nov-16 & 3 & $45-64$ & partly cloudy & slight breeze & Absent & $18: 00$ & 23:00 & 35 & game farm \\
\hline Safari Lodge, Victoria Falls, Zimbabwe & -17.92 & 25.82 & 18-Nov-16 & - & - & - & - & Absent & $18: 00$ & $22: 45$ & - & tourist lodge \\
\hline Pafuri River Lodge & -22.37 & 31.52 & 19-Nov-16 & 2 & & clear & no wind & Present & $18: 00$ & $23: 15$ & 200 & game farm \\
\hline Pafuri River Lodge & -22.37 & 31.52 & 20-Nov-16 & 2 & & clear & strong wind & Present & $18: 00$ & 23:00 & 95 & game farm \\
\hline Wallacedale & -22.95 & 29.92 & 3-Dec-16 & 2 & $20-40$ & clear & no wind & Present & $18: 15$ & 23:00 & 74 & homestead \\
\hline Mumie 36NT & -22.43 & 30.31 & 24-Nov-17 & 4 & $50-62$ & clear & slight breeze & Absent & $18: 30$ & 23:00 & - & - \\
\hline Kineaiv-Smith & -22.87 & 29.81 & 24-Nov-17 & 2 & 30 & clear & no wind & Present & $18: 30$ & 23:00 & - & - \\
\hline Princess Hill-1 & -22.86 & 29.81 & 24-Nov-17 & 2 & $30-40$ & overcast & no wind & Absent & $18: 15$ & $23: 15$ & - & game farm \\
\hline Princess Hill-2 & -22.87 & 29.81 & 24-Nov-17 & 2 & $50-55$ & overcast & no wind & Absent & $18: 15$ & $23: 30$ & - & game farm \\
\hline Venetia Nature Reserve (Faure Camp)) & -22.44 & 33.55 & 15-Nov-17 & 3 & $24-30$ & clear & no wind & Present & $18: 00$ & $21: 45$ & - & nature reserve \\
\hline Mapungubwe National Park (Picnic Baobab) & -22.20 & 29.38 & 16-Nov-17 & 3 & $24-30$ & overcast & slight breeze & Present & $18: 45$ & $21: 15$ & - & world heritage site \\
\hline Mapungubwe National Park (Camp Baobab) & -22.24 & 29.42 & 18-Nov-17 & 3 & $24-30$ & clear & no wind & Present & $18: 40$ & 21:00 & - & world heritage site \\
\hline Venetia Nature Reserve (Venetia Gate) & -22.26 & 29.32 & 23-Nov-17 & 5 & $20-54$ & clear & strong breeze & Present & $18: 30$ & $23: 15$ & - & nature reserve \\
\hline Mapungubwe National Park (Swing Baobab) & -22.20 & 29.37 & 17-Nov-17 & 3 & $24-30$ & slight breeze & no wind & Present & $18: 30$ & 21:00 & - & world heritage site \\
\hline Mapungubwe National Park (Camp Baobab) & -22.24 & 29.42 & 23-Nov-17 & 3 & $24-30$ & overcast & strong wind & Present & $18: 15$ & $23: 30$ & - & world heritage site \\
\hline Mapungubwe National Park (Zebra Pan) & -22.19 & 29.41 & 21-Nov-17 & 3 & $24-30$ & clear & no wind & Present & $18: 30$ & $24: 00$ & - & world heritage site \\
\hline Venetia Nature Reserve (Faure Camp) & -22.44 & 33.55 & 14-Nov-17 & 6 & $24-54$ & clear & no wind & Present & $18: 30$ & $21: 45$ & - & nature reserve \\
\hline Venetia Nature Reserve (Venetic Gate) & -22.26 & 29.32 & 20-Nov-17 & 3 & $24-30$ & clear & no wind & Present & $18: 45$ & $23: 30$ & - & nature reserve \\
\hline
\end{tabular}


In order to account for variation between nights and trees, results were plotted as means (and standard errors) of the number of visitors per person-hour per 15-min interval throughout the night, i.e., we divided the number of visitors by both the number of observers as well as the number of hours (0.25) per $15 \mathrm{~min}$ period. In order to test for possible biases due to year (2016 or 2017), observer expertise (experts such as students and researchers versus non-academics) and weather (fine or "bad", with bad defined as strong winds and/or rain), we conducted generalized linear models to test these predictors against each response variable (moth visitors to trees and flowers, bat visitors to trees and other visitors to trees and flowers). We first analyzed counts per night using a generalized linear model in R (version 3.1.0; R Core Team 2014), with a Poisson distribution and with an offset representing log (effort) (where effort represented person-hours). However, since all these models were significantly over-dispersed, we repeated the models specifying "family = quasipoisson" to estimate the overdispersion parameter. In all these final models, none of the categorical predictors (year, observer expertise and weather) were significant for any of the response variables (Appendix D).

\section{Results}

A total of 23 distinct baobab trees were monitored by citizen scientists, 11 of them over 14 nights between 6th November and 3rd December 2016, and a further 12 over 13 nights between 14th and 24th November 2017 (Table 1). The locations of these baobabs reflected the availability of public tourist lodges as well as farms belonging to private landowners that had accessible baobabs. All but two of the trees were in Limpopo Province, South Africa (mostly in the extreme north), with two trees in Zimbabwe, one at Victoria Falls in western Zimbabwe close to the Zambezi River, and the other at Chilo Gorge Lodge in southeastern Zimbabwe on the Save River close to the Mozambique border (Figure 1).

Citizen scientists who participated in the Baobab Blitz surveys were aged between 20 and 69 years. Baobab trees were monitored by groups ranging between 1 and 16 people (mean $=3.6$; Table 1$)$. On 17 of the nights, the groups comprised university students and researchers; other participants were retirees, a school teacher, a journalist, conservation officials, land owners and business people (including a financial consultant and a company director). Between zero (on one occasion) and 200 flowers were observed opening on a single tree, on a single night $(n=14$; mean $=58$; Table 1$)$.

In total, over the 2016 and 2017 flowering periods, during $117 \mathrm{~h}$ of observations, 575 baobab flower visitors and 1076 baobab tree visitors were recorded. In 2016, over $63 \mathrm{~h}$ of observations, tree visitors comprised 281 moths, 48 insectivorous bats and 86 other, while flower visitors comprised 129 moths, 1 fruit bat and 137 other. During 2017, over 54 h, tree visitors comprised 488 moths, 124 insectivorous bats, no fruit bats and 49 other, while flower visitors comprised 194 moths, no bats and 115 other.

A common pattern observed during both the 2016 and 2017 surveys was the predominance of moth visitors to both baobab trees (68\% and 74\% of visitors in 2016 and 2017, respectively) and flowers (48\% and 63\% in 2016 and 2017, respectively). In 2017, the mean number of moth numbers per person-minute peaked in the earlier part of the evening, but this was less clear in 2016 (Figures 2 and 3). Most of the moths were unidentified, but at least two species of hawkmoths were observed-Nephele comma and Sphingomorpha chlorea. The category "other" included predominantly beetles (including rose beetles and Christmas beetles, Family Scarabaeidae) as well as bees and other Hymenoptera, ants, dragonflies, unidentified insects, birds (including sunbirds) and lesser bush babies (Galago moholi). The bush babies were recorded at only two sites, Pafuri River Camp (on two nights) and Elgen (Skelmwater Research Plot) (on one night). At Pafuri River Camp, they were observed to feed on flowers, to spend about six minutes on the baobab tree, and to move frequently between trees (presumably including nearby baobab trees). The two peaks (and high standard errors) in "other" visits in 2016 were due to very high numbers of beetles observed visiting flowers at one location, Goro Game Reserve (Figure 3). These beetles were observed resting on old flowers (from the previous night).

Insectivorous bats were recorded quite commonly (12\% and 19\% of tree visitors in 2016 and 2017, respectively) throughout the night visiting baobab trees (presumably to feed on insects attracted by the 
flowers). Fruit bats were only observed visiting flowers at one location-a baobab tree at Chilo Gorge Lodge in Zimbabwe. Fruit bats (Epomophorus sp.) visiting the flowers came from a day roost in the thatched roof of the lodge just a few meters from the baobab tree. Fruit bats were observed visiting trees (but not flowers), on three occasions in 2016, at Goro Research Camp, Mogalakwena Research Center, and Pafuri River Camp (Table 1).

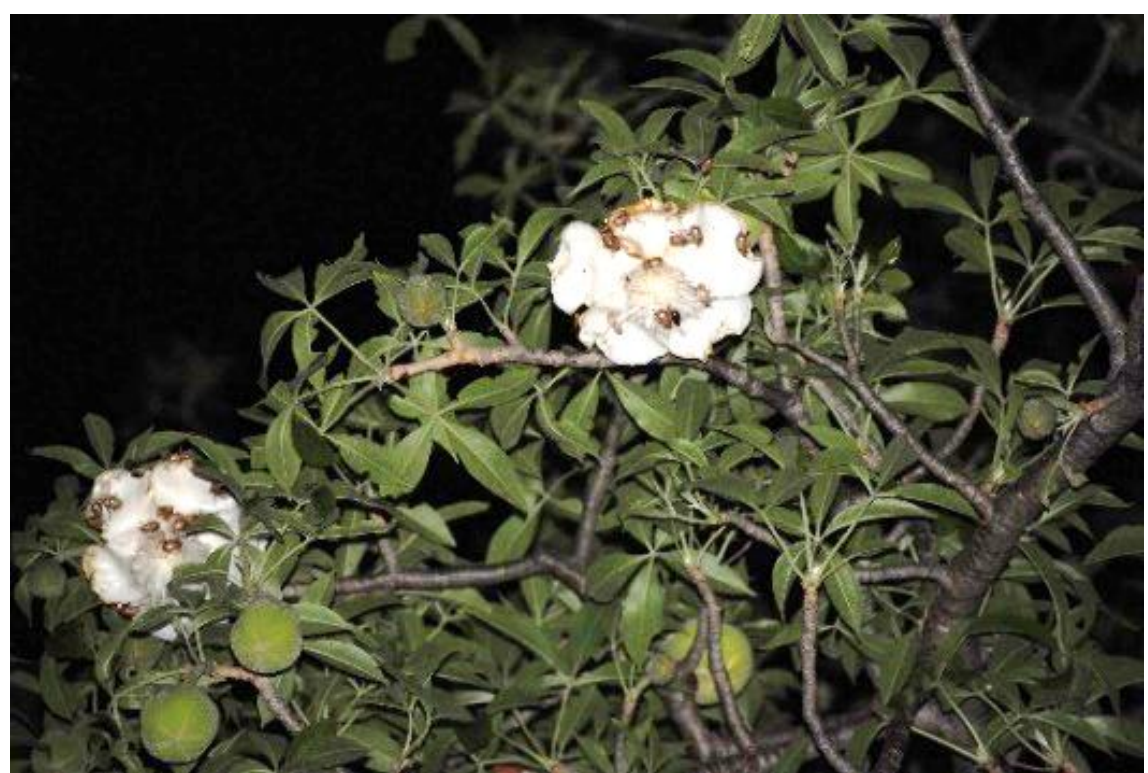

(a)

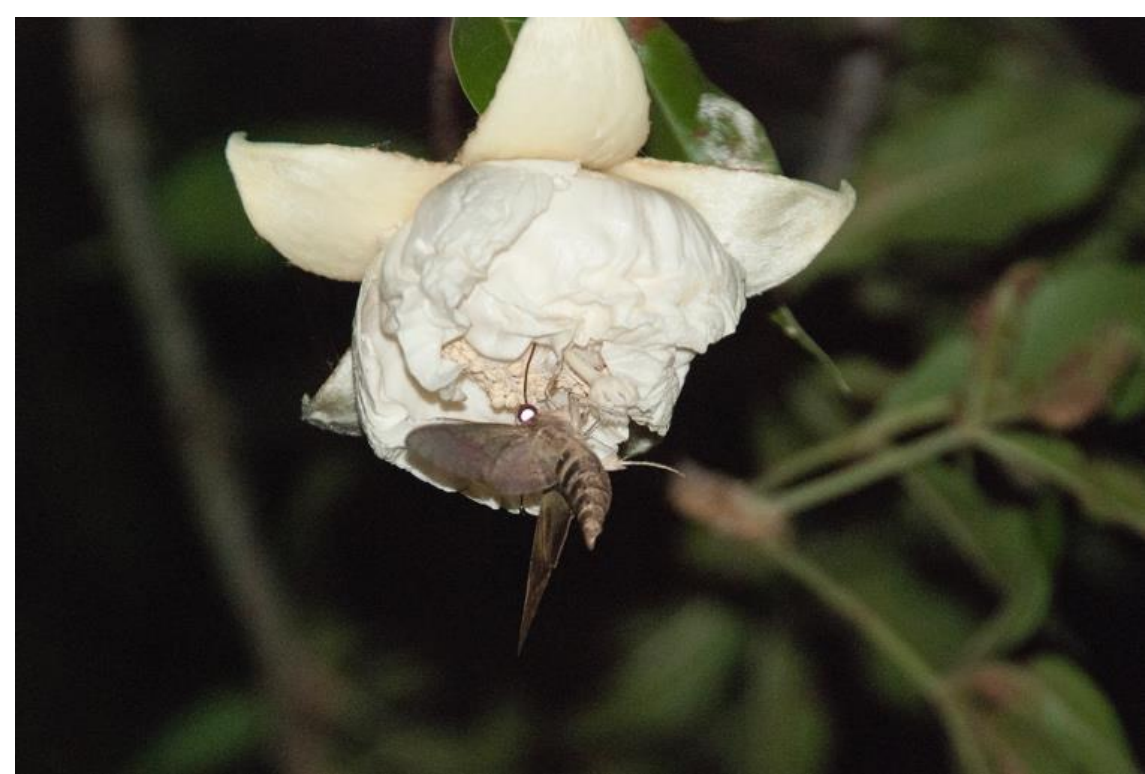

(b)

Figure 2. Cont. 


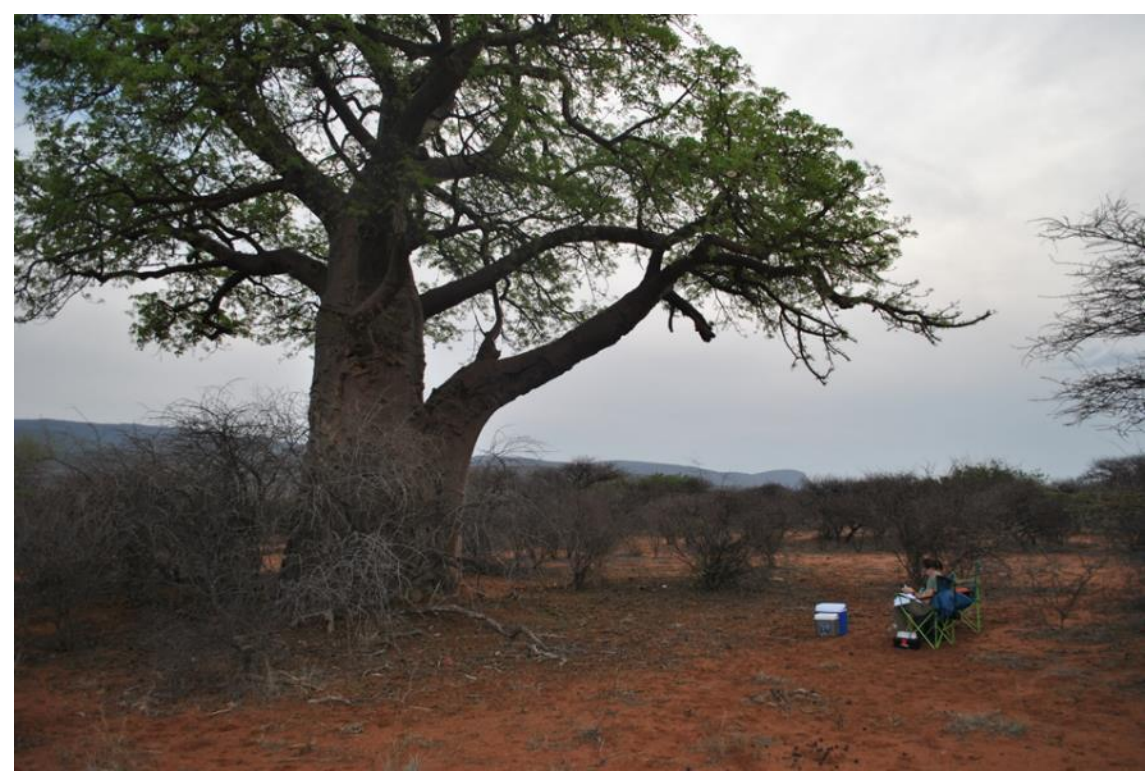

(c)

Figure 2. Photographs of (a) insect (scarab beetle), (b) hawkmoth (Nephele comma) visitors to baobab flower and (c) researchers preparing for a night of observations during the Baobab Blitz of 2016.

a) Mean tree visitors per person-minute (2016)

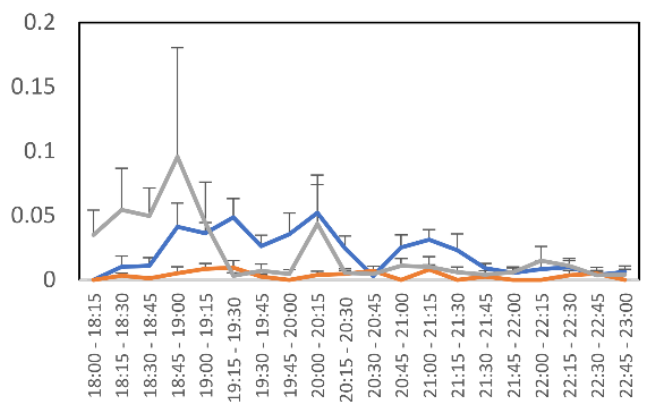

Moths —Insectivorous bats — Others b) Mean flower visitors per person-minute (2016)

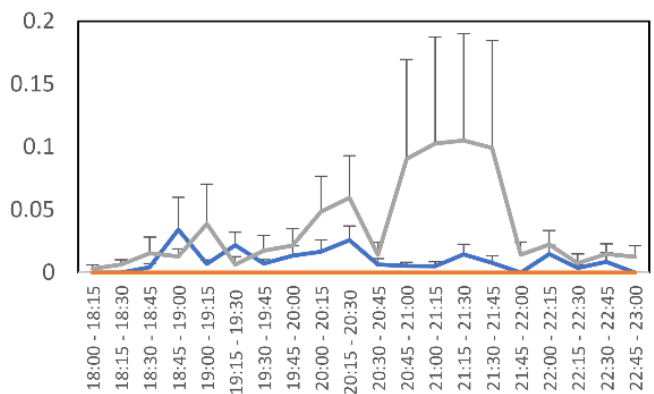

c) Mean tree visitors per person-minute (2017)

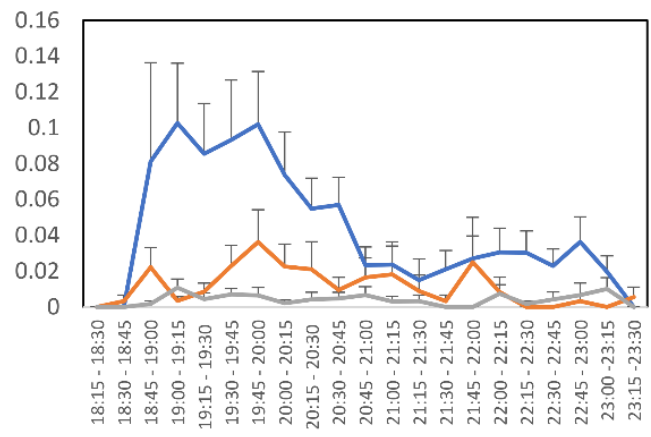

d) Mean flower visitors per person-minute (2017)

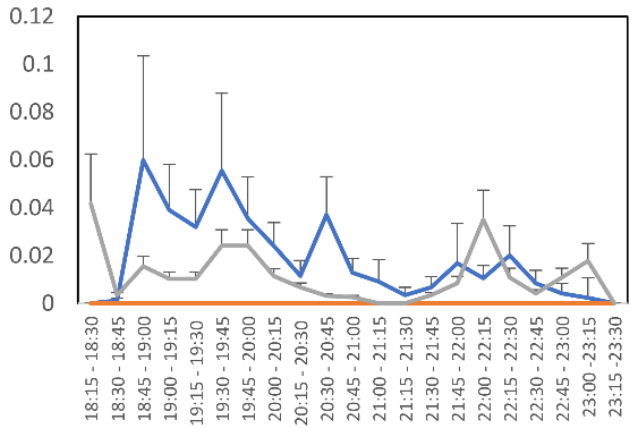

Figure 3. Mean (+ standard error) number of tree visitors $(\mathbf{a}, \mathbf{c})$ and flower visitors $(\mathbf{b}, \mathbf{d})$ of baobab trees monitored by citizen scientists in South Africa and Zimbabwe during the flowering season (November-December) during 2016 (a,b) and 2019 (c,d). For presentation, data points for fruit bat visitors not shown (see Results). 


\section{Discussion}

In 575 flower visitors at 23 baobab trees in South African and Zimbabwe during flowering periods from two years, we only obtained only a single incidence of a fruit bat (Epomophorus crypturus) visiting and feeding on baobab flowers, at Chilo Gorge Lodge in Zimbabwe. These observations revealed that flowers in South Africa were primarily visited by moths. By contrast, Andriafidison et al. [6] recorded between 5 and 30 visits an hour by the fruit bat Eidolon dupreanum to the Malagasy baobab Adansonia suarezensis throughout the duration of the night. In the above Madagascar study, fruit bats spent between 5 and $20 \mathrm{~s}$ at the flowers. They were observed to enfold the entire flower in their wings and to thrust their muzzles deep into the corolla to extract nectar. Likewise, Start [21] described over a hundred Egyptian fruit bats (Rousettus aegyptiacus) feeding on baobab flowers within two hours of anthesis near Mombasa, Kenya. Visits lasted 5 to $10 \mathrm{~s}$ before the bat dropped away from the flower covered in pollen and leaving the flowers with clearly defined claw marks on the petals. In West Africa, in Senegal and Benin, high rates of baobab flower visitation by Eidolon helvum was marked by a high prevalence of flowers having distinctive claw marks from the fruit bats $[17,35]$.

Taken together, our data starkly indicate an absence of fruit bat visits to baobab flowers in southern Africa, compared to frequent visits by moths. On occasion, hawkmoths were observed making contact with the anthers while extracting nectar from their long proboscis. There could be a number of reasons for the lack of fruit bat pollination, most possibly the low food availability and low fruit bat densities in northern Limpopo Province and southern Africa in the semi-arid areas where baobabs occur. In Benin, fruit bat pollination was found to be much lower in dry areas compared to wetter areas [35]. There are three fruit bat genera potentially occurring in our study area in southern Africa, and the distribution of specimen records seems to be closely tied to major river valleys (Figure 1). Riparian zones of major rivers such as the Limpopo and Zambezi contain suitable habitats where fruit bats occur. Since some of the baobab trees monitored in this study were located close to major rivers such as the Limpopo (Mapungubwe National Park) and Zambezi (Victoria Falls Lodge), we expected to observe fruit bat visitors, but this was not the case. The exception was a single fruit bat visit recorded at Chilo Gorge along the Save River, but here the fruit bats were roosting meters away from a flowering baobab.

Another possible reason for low bat visits may be differences in baobab flower scent between different regions of Africa. Baobab flowers in west Africa have been described as having an unpleasant sulfurous smell which is typical of bat-pollinated flowers [36], whereas the flower scent in southern Africa tends not to be as acrid (S.V., personal observation). Further investigation of the differences in flower scent would help determine if this played a role in attracting hawkmoths rather than bats to the flowers.

Our study was subject to several limitations. First, this was a spatio-temporal snapshot of visitors to baobabs. The number of citizen scientists recruited constrained the number of trees that could be observed, and each tree was only observed for one night and observations ceased at midnight. It is conceivable that bats visited flowers at other trees or on other nights, or after midnight, although in other areas of Africa where bats commonly pollinate flowers they are frequently observed on the flowers well before midnight [17]. Second, our observers included citizen scientists, researchers and students, presenting a possible bias due to observer expertise; on top of this we suspected that the weather (e.g., extremely windy or rainy nights), or the year of sampling, may present potential biases. We tested these by using generalized linear models to test the effect of three categorical predictor variables (observer expertise, weather and year of sampling) on each response variable (counts of different tree and flower visitors groups) except for bat visitors to flowers (since only one observation was noted). Our results showed the absence of any significant bias in any of these potentially confounding factors (Appendix D). Finally, presence of observers may potentially have deterred bats from visiting the baobab trees, but this has not been observed in other studies. To address some of these limitations, future research is being planned to use camera traps to constantly monitor baobab flowers throughout the night and to allow for human presence at the trees. 
Although baobabs are clearly being pollinated, as is evidenced by the abundant fruit on the trees a few months later, hawkmoths are very likely to be doing a poorer job of it than bats. Bats have a much larger body size allowing more pollen to be transported and are able to fly farther distances during foraging, thus bats would both be able to transfer more pollen from one flower to another and transport pollen further. Baobabs are obligate out-crossers [22], and thus the ability to transfer pollen to neighboring trees and to trees situated further away is important for pollination and long-term fitness. Baobab fruit size is generally smaller in southern African compared to other parts of Africa $[37,38]$ and genetic diversity may also possibly be limited which may have an interesting long-term effect on the southern African population. Lastly, further studies on the ecology and distribution of the dominant moth visitors is important. If the population of these pollinators were to crash, either due to climate change or widespread pesticide use, this would have a devastating effect on fruit production and the long-term survival of the population in this area and the livelihoods and income of the people who rely on these trees. Conservation efforts should focus on conserving the moths and ensuring that there are no negative impacts on the moths, such as the use of chemicals or protecting other species that the moths need in their life cycle. Thus, these results are of importance to policy makers and resource managers ensuring that management decisions take into account the importance of these pollinators.

Author Contributions: Conceptualization, P.J.T., S.V., T.K. and C.V.; formal analysis, M.A.K., P.J.T.; resources and funding acquisition, P.J.T.; data curation, M.A.K. and P.J.T.; writing-original draft preparation, P.J.T.; writing-review and editing, S.V., T.K., M.A.K. and C.V. All authors have read and agreed to the published version of the manuscript.

Funding: The funding of the Department of Science and Technology (DST) and the National Research Foundation (NRF) is acknowledged through the South African Research Chairs Initiative (SARChI) Chair on Biodiversity Value and Change, hosted at University of Venda and co-hosted by the Centre for Invasion Biology at University of Stellenbosch (NRF Grant number 87311).

Acknowledgments: Numerous students and researchers as well as citizen scientists are acknowledged for their great efforts in supporting this project. In particular, Murunwa Nelufule, Vusani Mphethe and Zwannda Nethavhani assisted greatly with monitoring of baobab trees at Mapungubwe National Park. We are grateful to Danny Govender from SanParks for arranging a permit to study bats at Mapungubwe National Park, and to Stefan Cilliers and Conrad Strauss for facilitating access to the Park. We are also grateful to the De Beers Consolidated Mines Group and Duncan MacFadyen of E. Oppenheimer and Sons for permission to conduct research on bats at Venetia Limpopo Nature Reserve, and to the Reserve Manager, Werner Taljaard for arranging access.

Conflicts of Interest: The authors declare no conflict of interest. The funders had no role in the design of the study; in the collection, analyses, or interpretation of data; in the writing of the manuscript, or in the decision to publish the results. 
Appendix A. Poster Advertising 2017 Baobab Blitz

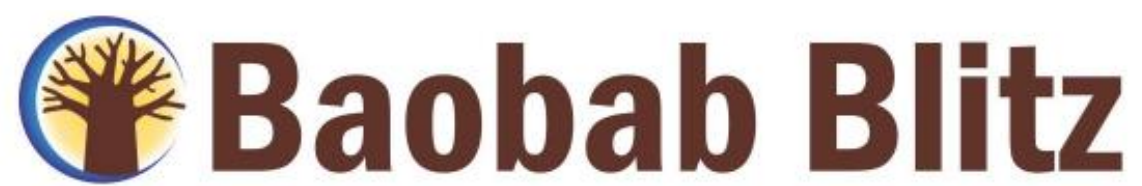

\section{What is pollinating baobab flowers?

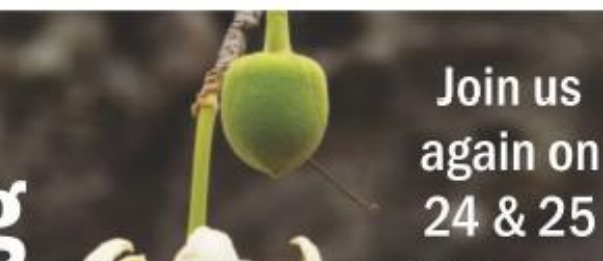 \\ November \\ and \\ $2 \& 3$ \\ December}

Bet you thought it was bats, but did you know that scientists have never seen bats visiting baobab flowers in Southern Africa?

We need your help to find out!

This year we will be adding to the data that was collected last year. Last year we found that only hawk moths were visiting baobab flowers in Gouth Africa, but to make absolutely sure of our conclusions we need to grow our osolutely sur and for this we need your help. If you have a back tree on your tarm or in your garden, please register and help us find ourt

Baobabs have flowers that are big, white and open at night. They can either be pollinated by bats or hawk-moths. Bats have been seen pollinating baobab flowers in East and West Africa, but never been seen pollinatin baobab flowers in Southern Africa. Baobab trees in our area flower from October to December each year. The peak flowering season is in November.

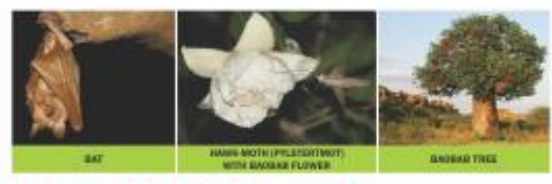

What you need to do:

When: 24-25 Nowember 2017 and/or 2-3 December 2017 (one or both nights, one or both weekends)

Where: Any baobab tree in Limpopo (Alldays, Vivo,

Waterpoort, Mopani, Musina, Tshipise, Pafuri).

How: Sit under one baobab tree from $6 \mathrm{pm}$ to $12 \mathrm{pm}$ and record what is coming to the flowers.

Register: Send us an e-mail, WhatsApp. Facebook

message or SMS so that we can send you a registration and infermation pect

Do you have a favourite baobab tree? How about spending a fun evening (with friends and family), watching its flowers open and at the same time help us collect Contact detalls:

Email: catheremembebiosphere ong whatsapp/SMS:071 4987551 Facebook: Bsobab Blitz Website: www.membebiosphere.org More information can be found on our website and facebook site (ब)

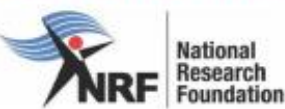

ECOProducts Foundation 


\section{Appendix B. Copy of Blank Form Used for Baobab Blitz (2017)}

For instructions on filling the datasheet, please refer to the information packet.

Name and surname:

Contact number:

Email:

About your group:

How many people in your group:

Age range of your group:

About your night:

Date (circle one): 24th Nov, 25th Nov, 2nd Dec, 3rd Dec, Other:

Time started observing:

Time ended observing:

Weather (circle one): Clear Partly cloudy Overcast Rain

Temperature beginning (if known)

Temperature end (if known):

Wind (circle one): No wind, Slight breeze, Strong wind

\section{About the tree:}

Farm name:

GPS coordinates or Description of where the tree is: eg: 10km east of Musina.:

Photo of tree (circle): Yes No

Photo of a flower: Yes No

Photos of tree and flower: attach via email 
Table A1. Copy of Blank Form Used for Baobab Blitz (2017).

\begin{tabular}{|c|c|c|c|c|c|c|c|}
\hline Interval & Moth Visitors to Tree & Moth Visitors to Flower & Bat Visitors to Tree & Bat Visitors to Flower & Other* Visitors to Tree & Other* Visitors to Flower & Comments \\
\hline \multicolumn{8}{|l|}{ 1-8 18:00-18:15 } \\
\hline \multirow{2}{*}{\multicolumn{8}{|c|}{ 1-8 18:15-18:30 }} \\
\hline \multirow{2}{*}{\multicolumn{8}{|c|}{$\begin{array}{l}1-818: 30-18: 45 \\
1-818: 45-19: 00\end{array}$}} \\
\hline & & & & & & & \\
\hline \multicolumn{8}{|l|}{ 1-8 19:00-19:15 } \\
\hline \multicolumn{8}{|l|}{ 1-8 19:15-19:30 } \\
\hline \multirow{2}{*}{\multicolumn{8}{|c|}{$\begin{array}{c}1-8 \text { 19:30-19:45 } \\
1-819: 45-20: 00\end{array}$}} \\
\hline & & & & & & & \\
\hline \multicolumn{8}{|l|}{ 1-8 20:00-20:15 } \\
\hline \multicolumn{8}{|l|}{ 1-8 20:15-20:30 } \\
\hline 1-8 Interval & Moth visitors to tree & Moth visitors to flower & Bat visitors to tree & Bat visitors to flower & Other* visitors to tree & Other* visitors to flower & Comments \\
\hline \multicolumn{8}{|l|}{$1-820: 30-20: 45$} \\
\hline \multicolumn{8}{|l|}{ 1-8 20:45-21:00 } \\
\hline \multirow{2}{*}{\multicolumn{8}{|c|}{ 1-8 21:00-21:15 }} \\
\hline & & & & & & & \\
\hline \multicolumn{8}{|l|}{$1-821: 30-21: 45$} \\
\hline \multicolumn{8}{|l|}{$1-8$ 21:45-22:00 } \\
\hline \multicolumn{8}{|l|}{ 1-8 22:00-22:15 } \\
\hline \multirow{2}{*}{\multicolumn{8}{|c|}{ 1-8 22:15-22:30 }} \\
\hline & & & & & & & \\
\hline \multicolumn{8}{|l|}{$1-8<22: 45-23: 00$} \\
\hline 1-8 Interval & Moth visitors to tree & Moth visitors to flower & Bat visitors to tree & Bat visitors to flower & Other* visitors to tree & Other* visitors to flower & Comments \\
\hline \multicolumn{8}{|l|}{$\begin{array}{c}\text { 1-8 23:00-23:15 } \\
\text { (optional) }\end{array}$} \\
\hline \multicolumn{8}{|l|}{$\begin{array}{c}\text { 1-8 23:15-23:30 } \\
\text { (optional) }\end{array}$} \\
\hline \multicolumn{8}{|l|}{$\begin{array}{l}\text { 1-8 23:30-23:45 } \\
\text { (optional) }\end{array}$} \\
\hline $\begin{array}{c}\text { 1-8 23:45-24:00 } \\
\text { (optional) }\end{array}$ & & & & & & & \\
\hline
\end{tabular}

* If other, please describe on following page or in comments section 
This page is for additional notes that you may have: 


\section{Appendix C. Baobab Blitz Information Packet}

Welcome to the Baobab Blitz! Thank you for participating in this citizen science project in order to help us discover what is pollinating baobab trees in South Africa.

\section{Instructions}

Be set up at your baobab tree before dark (approximately 5:30pm). This will allow you to fill out the sections that require light, including the number of other baobab trees surrounding yours and land use characteristics. Observing visitors to your baobab should be from $6 \mathrm{pm}$ to $11 \mathrm{pm}$ on either (or both) November 24th and November 25th or on the following weekend on the 2nd and 3rd December. If you wish to continue observing past $11 \mathrm{pm}$, we have included optional observing points on the datasheet. Fill out as much of the information on first page as possible before it gets dark. Counting the number of flowers open per night should wait until later after they've opened! Below are guides for each section.

\section{What you will need:}

- $\quad$ Torch (with extra batteries)

Red torch, if possible

- Chairs

- Cold drinks

- Cell phone camera (to take a photo of your tree and flower on that tree) or a normal camera that you can upload the photo.

- GPS or Smart phone to record your location (lat and long) or the farm name and where the tree is located.

- Clipboard with pen (extra one just in case)

- Datasheets, see attached via email (see BB Datasheet)

- Watch or phone (to record time)

- Other recommendations:

Table

Insect repellent

If you are observing multiple nights, please fill out separate datasheets for each night, including all of the information on the first page. If it is the same tree, some of this may be copied from the previous night (such as most of the tree characteristics and landscape characteristics). If you have multiple trees that your group is observing within visible distance from each other, please make an additional note of that on the datasheet as well as indicating the approximate distance between. 


\section{Datasheet Guide}

\section{Contact information:}

Please include this so that we can get in touch with questions.

\section{About your group:}

This information gives us a picture of who is participating in this event! If you wish, include pictures of your Baobab Blitz experience that we can share with others.

\section{About your night:}

Knowing what the night was like will help us to understand what is coming to visit the trees. For example, rainy nights may mean that pollinators may not come to visit the trees. They'd rather stay dry too!

Temperature: if you have a device on which you are able to take temperature, record the temperature when you start observing (beginning) and when you stop observing for the night (end).

\section{About the tree:}

This section gathers information about the tree itself.

GPS coordinates: include the latitude and longitude of the tree if possible. You can use a GPS or iPhone (the compass app). If you do not have a device with GPS, you can locate the tree on Google Maps later and include farm name.

Photos of tree and flower: include a picture of the full tree if possible. Also include a picture of one opened flower on the tree. See below for an example of opened and closed flowers (Figures A1 and A2).

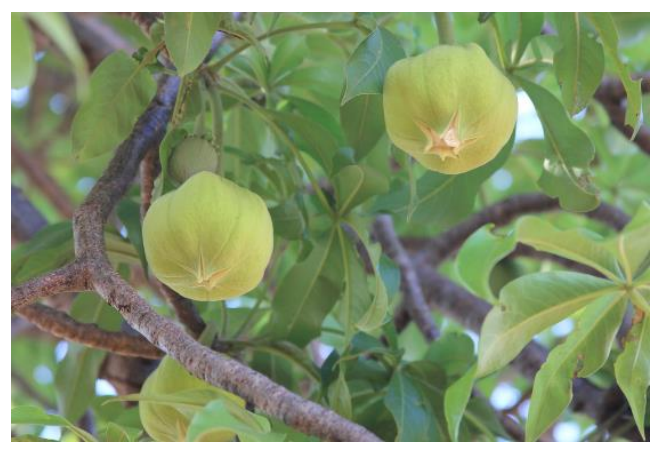

Figure A1. The bud on the right is cracked on the bottom, indicating that the flower will open that night while the bud on the left should remain closed. Photo @ Sarah Venter.

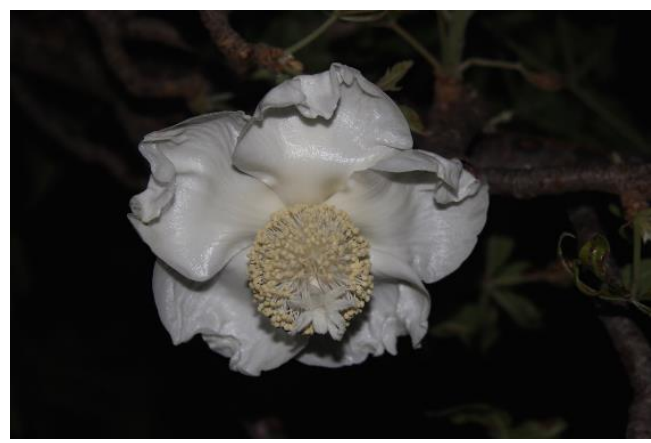

Figure A2. An open baobab flower. Photo (C) Sarah Venter.

\section{Visiting pollinator information:}

Now that we have discussed all of the valuable information that needs to be included about the observers, tree, and surrounding landscape, we finally get to the exciting part! 
Torch use: Do not leave strong torches aimed at the tree all night as this may deter pollinators! We recommend using red torches in preference to others as they are less disturbing to both bat and moth pollinators. If you want you can be inventive and create your own by using red ceolphane. No worries if you don't have a red light, a diffuse white light can be used. Additionally, being noisy and sitting directly under the tree could also deter pollinators!

When you begin observing, record the time that you started on your datasheet and begin in the appropriate time interval. Each pollinator visit to the tree will be tallied in the appropriate columns. For example, when you see a moth within the branches of the tree, that is one tick for Moth visitor to tree. Each time there is a visit to the flower (i.e., see the animal touch the flower in any way), that goes in visitor to flower under the appropriate animal or insect. When you have other visitors, please describe them in the comments section for that interval of observing.

If you leave the tree for a snack or break and miss observing during an interval, put a slash through that line of the datasheet. When you have zero pollinators that visit during a time interval, please put a zero.

As you get more comfortable, you may wish to differentiate between the moths that come. For example, hawkmoths tend to be faster flying moths than other species. You may wish to include how many fast flying and slow flying moths in your comments.

Similarly, there are differences in bats. We are interested in fruit bats visiting trees, not their smaller insectivorous cousins. Below are some ways to tell them apart.

Fruit Bats:

- $\quad$ Eat fruit and nectar

- Larger that insectivorous bats (usually)

- Do not echolocate

- Our ears can detect their metallic "ping ping" calls.

- Forage for many hours throughout the night.

- Should land on the flower to drink the nectar from behind the petals.

Insectivorous bats:

- $\quad$ Eat insects

- Use echolocation

- Call is above most people's hearing

- Usually smaller and faster flying than fruit bats.

- Tend to forage most just after sunset and again before sunrise

- Will not land on the flower but might fly fast through the tree chasing an insect.

As always, you should be vigilant of your surroundings in the bush and watch for things like scorpions crawling around at night. 


\section{Appendix D.}

Table A2. Generalized linear models with quasipoisson correction and offset to correct for effort (log (person-hours)), for the relationship of different tree and flower visitor counts per tree-night with observer qualification (expert or not), weather (fine or bad), and year (2016 or 2017). Variables were compared with default values for Expert ("Yes"), Weather ("Fine"), and Year (2017). Thus, Year tests for differences between 2016 and 2017 and a negative estimate indicates lower activity in 2016 compared with 2017. $P(>|z|)$ is the tail area in a 2-tail test, with the $z$ value as the Wald statistic for testing the hypothesis that the regression coefficient is zero.

\begin{tabular}{lllll}
\hline (a) Moth Visitors to Tree & Estimate & Std. Error & z Value & Pr $(>|\mathbf{z}|)$ \\
\hline (Intercept) $=0$ & -0.3373 & 0.5174 & -0.652 & 0.514 \\
as.factor (Year) 2017 $=0$ & 0.4832 & 0.3218 & 1.502 & 0.133 \\
as.factor (Expert) Yes $=0$ & 0.5736 & 0.4097 & 1.400 & 0.161 \\
as.factor (Weather) Fine $=0$ & 0.6001 & 0.3986 & 1.505 & 0.132 \\
(b) Moth visitors to flower & & & & \\
(Intercept) $=0$ & -1.9575 & 0.9562 & -2.047 & $0.0406^{*}$ \\
as.factor (Year) 2017 $=0$ & 0.3737 & 0.4953 & 0.755 & 0.4505 \\
as.factor (Expert) Yes $=0$ & 0.9865 & 0.7280 & 1.355 & 0.1754 \\
as.factor (Weather) Fine $=0$ & 1.1070 & 0.7165 & 1.545 & 0.1223 \\
(c) Bat visitors to tree & & & & \\
(Intercept) $=0$ & -2.6659 & 0.9627 & -2.769 & $0.00562 * *$ \\
as.factor (Year) 2017 $=0$ & 0.9878 & 0.5339 & 1.850 & 0.06429 \\
as.factor (Expert) Yes $=0$ & 1.1892 & 0.7956 & 1.495 & 0.13501 \\
as.factor (Weather) Fine $=0$ & 0.5044 & 0.6074 & 0.831 & 0.40625 \\
(d) Other visitors to tree & & & & \\
(Intercept) $=0$ & -1.5791 & 1.6047 & -0.984 & 0.325 \\
as.factor (Year) 2017 $=0$ & -1.4977 & 1.0930 & -1.370 & 0.171 \\
as.factor (Expert) Yes $=0$ & 1.2967 & 1.4412 & 0.900 & 0.368 \\
as.factor (Weather) Fine $=0$ & 0.9304 & 1.0392 & 0.895 & 0.371 \\
(e) Other visitors to flower & & & & \\
(Intercept) $=0$ & -0.8228 & 2.0139 & -0.409 & 0.683 \\
as.factor (Year) 2017 $=0$ & -1.1185 & 1.1535 & -0.970 & 0.332 \\
as.factor (Expert) Yes $=0$ & 1.7130 & 1.9606 & 0.874 & 0.382 \\
as.factor (Weather) Fine $=0$ & 0.1434 & 1.0045 & 0.143 & 0.886 \\
\hline denotes significance at $p<0.05$ level; ${ }^{* *}$ denotes significance at $p<0.01$ level; no asterisk denotes non-significance
\end{tabular}

\section{References}

1. Harris, B.J.; Baker, H.G. Pollination of flowers by bats in Ghana. Niger. Field 1959, 24, 154-159.

2. Ayensu, E.S. Plant \& bat interactions in West Africa. Ann. Mo. Bot. Gard. 1974, 61, 702-727.

3. Fujita, M.S. Flying fox (Chiroptera: Pteropodidae) pollination, seed dispersal, and economic importance. In A Tabular Summary; Bat Conservation International (Resource Publication No. 2): Austin, TX, USA, 1991.

4. Barclay, R.M.R. Do plants pollinated by flying fox bats (Megachiroptera) provide an extra calcium reward in their nectar? Biotropica 2002, 34. [CrossRef]

5. Hodgkinson, R.; Balding, S.T.; Zubaid, A.; Kunz, T.H. Fruit Bats (Chiroptera: Pteropodidae) as seed dispersers and pollinators in a lowland Malaysian rain forest. Biotropica 2003, 35, 491-502. [CrossRef]

6. Andriafidison, D.; Andrianaivoarivelo, R.A.; Ramilijaona, O.R.; Andrianaivoarivelo, R.A.; Racey, P.A.; Razafindrakoto, N.; Jenkins, R.K.B. Nectarivory by endemic Malagasy fruit bats during the dry season. Biotropica 2006, 38, 85-90.

7. Bumrungsri, S.; Harbit, A.; Benzie, C.; Carmouche, K.; Sridith, K.; Racey, P. The pollination ecology of two species of Parkia (Mimosaceae) in southern Thailand. J. Trop. Ecol. 2008, 24, 467-475. [CrossRef]

8. Bumrungsri, S.; Lang, D.; Harrower, C.; Sripaoraya, E.; Kitpipit, K.; Racey, P.A. The dawn bat, Eonycteris spelaea Dobson (Chiroptera: Pteropodidae) feeds mainly on pollen of economically important food plants in Thailand. Acta Chiropterol. 2013, 15, 95-104. [CrossRef] 
9. Fleming, T.H.; Geiselman, C.; Kress, W.J. The evolution of bat pollination: A phylogenetic perspective. Ann. Bot. 2009, 104, 1017-1043. [CrossRef] [PubMed]

10. Faigri, K.; Van der Pijl, L. The Principles of Pollination Ecology; Pergamon Press: Oxford, UK, 1979.

11. Fenster, C.B.; Armbruster, W.S.; Wilson, P.; Dudash, M.R.; Thomson, J.D. Pollination syndromes and floral specialization. Annu. Rev. Ecol. Evol. Syst. 2004, 35, 375-403. [CrossRef]

12. Waser, N.M. Specialization and generalization in plant-pollinator interactions: An historical perspective. In Plant-Pollinator Interactions: From Specialization to Generalization; Waser, N.M., Ollerton, J., Eds.; University of Chicago: Chicago, IL, USA, 2006; pp. 3-17.

13. Nathan, P.T.; Raghuram, H.; Elangovan, V.; Karuppudurai, T.; Marimuthu, G. Bat pollination of kapok tree Ceiba pentandra. Curr. Sci. 2005, 88, 1679-1681.

14. Srithongchuay, T.; Bumrungsri, S.; Sripao-raya, E. The pollination ecology of the late-successional tree, Oroxylum indicum (Bignoniaceae) in Thailand. J. Trop. Ecol. 2008, 24, 477-484. [CrossRef]

15. Bumrungsri, S.; Sripaoraya, E.; Chongsiri, T.; Sridith, K.; Racey, P.A. The pollination ecology of durian (Durio zibethinus, Bombacaceae) in southern Thailand. J. Trop. Ecol. 2009, 25, 85-92. [CrossRef]

16. Sidibe, M.; Williams, J.T. Baobab; Adansonia Digitata International Centre for Underutilised Crops: Southampton, UK, 2002.

17. Wickens, G.E.; Lowe, P. The Baobabs: Pachycauls of Africa, Madagascar and Australia; Springer: Berlin, Germany, 2008.

18. Venter, S.M.; Witkowski, E.T.F. Baobab (Adansonia digitata L.) density, size-class distribution and population trends between four land-use types in northern Venda, South Africa. For. Ecol. Manag. 2010, 259, $294-300$. [CrossRef]

19. Leong Pock Tsy, J.M.; Lumaret, R.; Mayne, D.; Vall, A.O.; Abutaba, Y.I.; Sagna, M.; Rakotondralambo Raoseta, S.O.; Danthu, P. Chloroplast DNA phylogeography suggests a West African centre of origin for the baobab, Adansonia digitata L. (Bombacoideae, Malvaceae). Mol. Ecol. 2009, 18, 1707-1715. [CrossRef]

20. Baum, D.A. The comparative pollination and floral biology of baobabs (Adansonia, Bombacaceae). Ann. Mo. Bot. Gard. 1995, 82, 322-348. [CrossRef]

21. Start, T. Pollination of the baobab (Adansonia digitata L.) by the fruit bat Rousettus. East Afr. Wildl. J. 1972, 10, 71-72. [CrossRef]

22. Venter, S.M.; Glennon, K.L.; Witkowski, E.T.F.; Baum, D.; Cron, G.V.; Tivakudze, R.; Karimi, N. Baobabs (Adansonia digitata L.) are self-incompatible and 'male' trees can produce fruit if hand-pollinated. S. Afr. J. Bot. 2017, 109, 263-268. [CrossRef]

23. Wilson, D.E.; Mittermeier, R.A. Handbook of the Mammals of the World, Volume 9: Bats; Lynx Edicions: Barcelona, Spain, 2019.

24. Monadjem, A.; Taylor, P.J.; Cotterill, F.P.D.; Schoeman, M.C. Bats of Southern and South-Central Africa: A Biogeographic and Taxonomic Synthesis; Wits University Press: Johannesburg, South Africa, 2010; p. 596.

25. Welford, W.; Venter, S.; Dohse, C. Harvesting from the tree of life-responsible commercialization of baobab in South Africa and Malawi. In Ecological Sustainability for Non-Timber Forest Products; Shackleton, C.M., Pandey, A.K., Ticktin, T., Eds.; Oxon: Routledge, UK, 2015.

26. Dickinson, J.L.; Shirk, J.; Bonter, D.; Bonney, R.; Crain, R.L.; Martin, J.; Phillips, T.; Purcell, K. The current state of citizen science as a tool for ecological research and public engagement. Front. Ecol. Environ. 2012, 10, 291-297. [CrossRef]

27. Mucina, L.; Rutherford, M.C. The Vegetation of South Africa, Lesotho and Swaziland; South African Biodiversity Instutute: Pretoria, South Africa, 2006.

28. Robinson, G.A. Limpopo Valley National Park: Towards Trans-Frontier Conservation in South Africa; South African National Parks: Pretoria, South Africa, 1996.

29. Van Wilgen, N.J.; Goodall, V.; Holness, S.; Chown, S.L.; McGeoch, M.A. Rising temperatures and changing rainfall patterns in South Africa's national parks. Int. J. Climatol. 2016, 36, 709-721. [CrossRef]

30. Van Wilgen, N.J.; Herbst, M. Taking Stock of Parks in a Changing World: The SANParks Global Environmental Change Assessment; SANParks: Cape Town, South Africa, 2017.

31. Venter, S.M.; Witkowski, E.T.F. Phenology, flowering and fruit-Set patterns of baobabs, Adansonia digitata, in southern Africa. For. Ecol. Manag. 2019, 453, 117593. [CrossRef]

32. Everyone Can Become A Baobab Scientist. Available online: https://zoutpansberger.co.za/articles/news/ 39227/2016-10-15/everyone-can-become-a-baobab-blitz-scientist (accessed on 13 March 2020). 
33. More Research on Baobab Pollinators. Available online: https://zoutpansberger.co.za/articles/news/41377/ 2017-03-23/more-research-needed-on-baobab-pollinators (accessed on 13 March 2020).

34. Help Solve Baobab Flower Mystery. Available online: https://www.zoutpansberger.co.za/articles/news/ 45072/2017-11-25/help-solve-baobab-flower-pollination-mystery (accessed on 13 March 2020).

35. Djossa, B.A.; Toni, H.C.; Adekanmbi, I.D.; Tognon, F.K.; Sinsin, B.A. Do flying foxes limit flower abortion in African baobab (Adansonia digitata)? Case study in Benin, West Africa. Fruits 2015, 70, 281-287. [CrossRef]

36. Pettersson, S.; Ervik, E.; Knudsen, J.T. Floral scent of bat-pollinated species: West Africa vs. the New World. Biol. J. Linn. Soc. 2004, 82, 161-168. [CrossRef]

37. Venter, S.M.; Witkowski, E.T.F. Fruits of our labour: Contribution of commercial baobab (Adansonia digitata L.) fruit harvesting to the livelihoods of marginalized people in northern Venda, South Africa. Agrofor. Syst. 2012, 87, 159-172. [CrossRef]

38. Omondi, M.; Rimberia, F.K.; Wainaina, C.M.; Mukundi, J.B.N.; Orina, J.; Gebauer, J.; Kehlenbeck, K. Fruit morphological diversity and productivity of baobab (Adansonia digitata L.) in coastal and lower eastern Kenya. For. Trees Livelihoods 2019, 28, 266-280. [CrossRef]

(C) 2020 by the authors. Licensee MDPI, Basel, Switzerland. This article is an open access article distributed under the terms and conditions of the Creative Commons Attribution (CC BY) license (http://creativecommons.org/licenses/by/4.0/). 